\title{
Response of two sorghum genotypes to foliar spray by different zinc oxide nanoparticles concentrations
}

\author{
Aml A. Tag El-Din \\ Department of Grain Sorghum Research, Field Crops Research Institute, Agriculture Research Center, Giza, Egypt
}

\begin{abstract}
A field experiment was carried out during 2017 and 2018 summer seasons at Arab El-Awamer Station, Assiut, Egypt to study the response of two sorghum cultivars to foliar spray by different zinc oxide nanoparticles concentrations. The field experiment was carried out in a randomized complete block design using a strip plot arrangement with three replications. Zinc oxide nanoparticles (ZnO NPs) concentrations (control, 50, 100, $150 \mathrm{ppm}$ ) were allotted horizontally, while two genotypes of sorghum (Giza 15 and Dorado) were assigned vertically. The obtained results showed that plant height, panicle length, panicle width, 1000 kernel weight and grain yield / plant were affected highly significant or significant by different zinc oxide nanoparticles in the two growing seasons, except 50\% flowering was insignificant in both seasons. Grain sorghum plants which were sprayed by 1 ' ppm $\mathrm{ZnO}$ NPs gave the highest mean values of grain yield /plant over both cultivars (44.87 and $44.90 \mathrm{~g}$ ), as against ( 40.10 and $39.92 \mathrm{~g}$ ) in control plants for the first and the second season, respectively. The same trend was observed for 1000-kernel weight, since the highest mean values of two cultivars obtained from plants which sprayed by 100 ppm $\mathrm{ZnO} \mathrm{Nps}$ (32.23 and $32.55 \mathrm{~g}$ ) with compared to control plants (28.25 and $28.45 \mathrm{~g}$ ) for both seasons, respectively. The interaction between $\mathrm{ZnO}$ NPs concentrations and genotypes had a non significant effect on the all studied traits in the first season, while in the second season the interaction between $\mathrm{ZnO}$ NPs concentrations and genotypes had significant effects on plant height, panicle length, grain yield / plant and $100 \cdot$ kernel weight.
\end{abstract}

Keywords : Grain sorghum ; Zinc Oxide Nanoparticles.

\section{Introduction}

Grain sorghum (Sorghum bicolor L. Moench) can grow as fodder and for human consumption in areas relay under water stress. Sorghum has a high concentration of potassium and starch, it is less acidifying and is easily absorbed and tolerated by the sick and diabetics, adults and even children. Sorghum is a substitute for wheat and is great for those requiring a gluten-free diet. Sorghum is naturally high in fiber and iron, with a high protein level as well (Pontieri et al.,

\footnotetext{
*Corresponding author: Aml A. Tag El-Din,

Email: amltag@yahoo.com

Received: June 18, 2021; Accepted: July 12, 2021;

Published online: July 20, 2021.

(C) Published by South Valley University.

This is an open access article licensed under $@()(2)$
}

2010). Dy Kes and Rooney (2006) reported that sorghum is rich in antioxidants, which are believed to help lower the risk of cancer, diabetes, heart disease and some neurological diseases. Sorghum produces much more forage than maize. Zinc $(\mathrm{Zn})$ is an essential nutrient required by all living organisms and represents the nanoparticles (NPs) with very small particles and large surface area are expected to be the ideal material for use as a $\mathrm{Zn}$ fertilizer in plants. Currently use of nanomaterial's has been expanded in every fields of science including agriculture. It has been stated that application of micronutrient fertilizers in the form of NPs is an important route to release required nutrients gradually and in a controlled way, which is essential to mitigate the problems of fertilizer 
pollutions Naderi and Abedi, 2012). It is because of that when materials are transformed to a nanoscale, they change their physical, chemical and biological characteristics as well as catalytic properties and even more increase the chemical and biological activities (Mazaherinia et al., 2010). Reynolds, (2002) demonstrated that micronutrients in the form of NPs can be used in crop production to increase yield. Currently Prasad et al. (2012) studied the effect of nanoscale zinc oxide on the germination, growth and yield of peanut and observed significantly more growth and yield. Sustainable agriculture mainly aims to reduce application of chemical fertilizer and minimize nutrient losses in fertilization and increase yields through optimized nutrient management. Recently, nanotechnology is coming into focus because nano particles (NPs) are small in size $(<100 \mathrm{~nm})$ having high surface area and reactivity. Recent studies revealed that powder or nano sized particles are found to be effective in absorption and translocation. However, physiological aspects of nano zinc application and its accumulation in grains crops are meager. Decreased particle size increased number of particles per unit weight of applied $\mathrm{Zn}$, also, increases the specific surface area of a fertilizer, which should increase the dissolution rate of fertilizers with low solubility in water such as zinc oxide (Mortvedt, 1992). Hence, the present study was carried out to investigate the effects of various concentrations of Zinc Oxide $(\mathrm{ZnO}) \mathrm{NPs}$ on yield attributes in grain sorghum.

\section{Materials and Methods}

This study was carried out during 2017 and 2018 summer seasons at newly reclaimed soil in the Agricultural Research Centre, the Arab ElAwamer Station, Assiut, Egypt to study the effect of foliar spray by different zinc oxide nanoparticles concentrations on grain yield and its components on two grain sorghum cultivars (Dorado and Giza -15) after 45 days from sowing. Chemical analyses of the experimental soil are presented in Table 1.

Table 1. Some physical and chemical properties of experimental sites.

\begin{tabular}{ccc}
\hline Properties & \multicolumn{2}{c}{ Arab El Awamer } \\
\cline { 2 - 3 } Mechanical analysis: & 2017 & 87.2018 \\
Sand (\%) & 85.40 & 7.20 \\
Silt (\%) & 8.70 & 5.60 \\
Clay (\%) & 5.90 & 0.77 \\
Texture & & 8.43 \\
Chemical analysis: & 0.59 & 0.04 \\
EC (1:1 extract) (dsm-1) & 8.21 & 4.88 \\
pH (1:1 suspension) & & 0.12 \\
Available & 0.06 & 32.15 \\
Total nitrogen (\%) & 5.14 & 0.14 \\
NaHCO3-extractable P (ppm) & 27.33 & \\
NaOC-extractable K (ppm) & 0.82 & \\
Oral CaCO3 \% (ppm) & & \\
\hline
\end{tabular}

\subsection{Experimental treatments and design}

The experiment was laid out in randomized complete block design (RCBD) using strip split 
plot arrangement with three replications. Zinc dioxide nanoparticles size (control, 50, 100, 150 ppm) were allocated horizontally, while genotypes of sorghum (Dorado, Giza -15) were arranged vertically in sub plots.

\subsection{Cultural practices}

Grain sorghum seeds were hand sown on rows of $3 \mathrm{~m}$ long and $60 \mathrm{~cm}$ apart with $25 \mathrm{~cm}$ between hills on $2^{\text {nd }}, 23^{\text {rd }}$ of June in the first and second seasons, respectively. Control plants were treated with water (without $\mathrm{ZnO}$ NPs) while the others were sprayed by the certain concentration of $\mathrm{ZnO}$ NPs. All sprayed treatments were done at 45 days after sowing. All other recommended cultural practices for grain sorghum crop were done in both seasons.

\subsection{Statistical analysis}

All collected data were subjected to the analysis of variance (ANOVA), procedures (Gomez and Gomez; 1984), using the SAS Statistical Software Package v.9.2 (SAS, 2008). Differences between means were compared by revised least significant difference (LSD) at $5 \%$ level of significant (El-Rawi and Khalafalla, 198

Table 2. Effect of zinc oxide nanoparticles concentrations, grain sorghum cultivars and their interaction on plant height/plant.

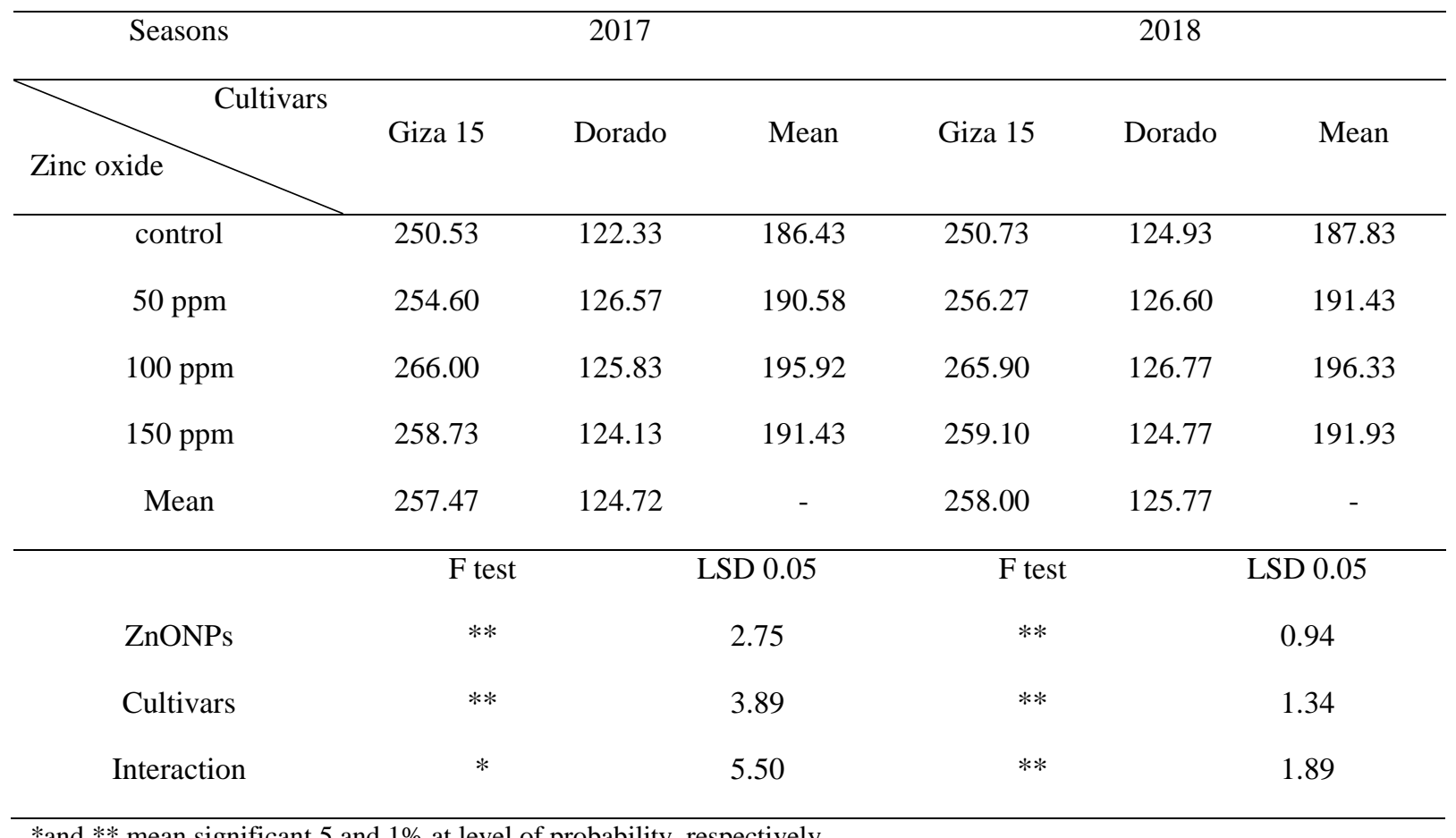

\section{Results and Discussion}

\subsection{Growth and Yield components traits}

The presented data in Tables (2- 6) reveal that the studied zinc oxide nanoparticles (ZnO NPs) concentrations had a significant or highly significant $(\mathrm{P} \leq 0.05$ or $\mathrm{P} \leq 0.01)$ effect on all studied traits in the two growing seasons except $50 \%$ flowering was no significant in both seasons. The interaction between $\mathrm{ZnO}$ NPs concentrations and grain sorghum cultivars had a significant or highly significant effect on plant height in the first and second season, respectively. Thus, the highest mean values of plant height (195.92 and $196.33 \mathrm{~cm}$ in the two respective seasons), as against (186.43 and $187.83 \mathrm{~cm}$ in control plants), were obtained from grain sorghum plants which were sprayed by 
$\mathrm{ZnO}$ NPs concentration at $100 \mathrm{ppm}$ Table2. The plants treated at the concentration of $100 \mathrm{ppm}$ $\mathrm{ZnO}$ NPs initiated flowering after (80.50 and 79.67 day) in the two respective seasons, as against ( 82.33 day in both seasons in control plants), no significant for the interaction between $\mathrm{ZnO}$ NPs concentrations and grain sorghum cultivars in both seasons on $50 \%$ flowering (Table 3). Concerning the interaction effect on panicle length trait, the exhibited data in Table 4 reveal that the interaction between $\mathrm{ZnO}$ NPs concentrations and grain sorghum cultivars had a significant effect in this respect during the second season only. The highest mean values of panicle length (22.27 and 22.35 $\mathrm{cm})$ in the two respective seasons, as against (20.10 and $20.17 \mathrm{~cm}$ in control plants) in the two respective seasons. Also, the recorded data in
Table 5 denote that the tested grain sorghum cultivars had no significant influence on panicle width in the two seasons, respectively. The highest mean values of panicle width (8.90 and $9.00 \mathrm{~cm}$ in the two respective seasons, as against $(8.03$ and $8.12 \mathrm{~cm})$ in control plants. Here too, the exhibited data in Tables 6, 7 denote that the interaction between $\mathrm{ZnO}$ NPs concentrations and grain sorghum cultivars had a significant effect on grain yield and 1000 kernel weight in the second season. The highest mean values of grain yield (44.87 and $44.90 \mathrm{~g}$ ) in the two respective seasons, as against (40.10 and $39.92 \mathrm{~g}$ ) in control plants. While, for 1000 kernel weight the highest mean values ( 32.23 and $32.55 \mathrm{~g})$ in the two seasons respectively, as against $(28.25$ and $28.45 \mathrm{~g}$ ) in control plant

Table 2. Effect of zinc oxide nanoparticles concentrations, grain sorghum cultivars and their interaction on plant height/plant.

\begin{tabular}{|c|c|c|c|c|c|c|}
\hline Seasons & \multicolumn{3}{|c|}{2017} & \multicolumn{3}{|c|}{2018} \\
\hline Zinc oxide Cultivars & Giza 15 & Dorado & Mean & Giza 15 & Dorado & Mean \\
\hline control & 250.53 & 122.33 & 186.43 & 250.73 & 124.93 & 187.83 \\
\hline $50 \mathrm{ppm}$ & 254.60 & 126.57 & 190.58 & 256.27 & 126.60 & 191.43 \\
\hline $100 \mathrm{ppm}$ & 266.00 & 125.83 & 195.92 & 265.90 & 126.77 & 196.33 \\
\hline $150 \mathrm{ppm}$ & 258.73 & 124.13 & 191.43 & 259.10 & 124.77 & 191.93 \\
\hline Mean & 257.47 & 124.72 & - & 258.00 & 125.77 & - \\
\hline & $\mathrm{F}$ te & & LSD 0.05 & F te & & LSD 0.05 \\
\hline ZnONPs & $* *$ & & 2.75 & $* *$ & & 0.94 \\
\hline Cultivars & $* *$ & & 3.89 & $* *$ & & 1.34 \\
\hline Interaction & $*$ & & 5.50 & $* *$ & & 1.89 \\
\hline
\end{tabular}

*and $* *$ mean significant 5 and $1 \%$ at level of probability, respectively.

The study shows that, by using a very less quantity of fertilizers may reduce the application doses of fertilizers, wastage of fertilizers, environmental hazards and increase nutrient use efficiency. There is need to study the effects of nano zinc oxide particles on soil beneficial microorganisms and different beneficial process like nitrification, nitrogen fixation, decomposition of organic material, mineralization, and immobilization. There is also need to standardize the nano fertilizers doses for different crop and optimum stage of crop for to achieve better crop production and also need to know the intra and extra cellular mechanisms involved in uptake and translocation of nanoparticles. In conclusion, foliar fertilization of $100 \mathrm{ppm} \mathrm{ZnO}$ was found more effective than other concentrations (50 and $150 \mathrm{ppm} \mathrm{ZnO}$ ). It is worth mentioning that higher/toxic doses of ZnO NPs i.e. >1000 ppm caused significant reduction in grain yield of sorghum (Poornima and Koti (2019), so it 
clearly indicates that nano particles are efficient and helps in increasing yield at much lower concentrations itself as compared to bulk forms of zinc and the results were in accordance with the reports on radish, rape, corn, lettuce and cucumber by Lin and Xing, (2007).

Table 3. Effect of zinc oxide nanoparticles concentrations, grain sorghum cultivars and their interaction on $\% 50$ flowering.

\begin{tabular}{|c|c|c|c|c|c|c|}
\hline Seasons & \multicolumn{3}{|c|}{2017} & \multicolumn{3}{|c|}{2018} \\
\hline Zinc oxide & Giza 15 & Dorado & Mean & Giza 15 & Dorado & Mean \\
\hline control & 81.33 & 83.33 & 82.33 & 82.00 & 82.67 & 82.33 \\
\hline $50 \mathrm{ppm}$ & 81.00 & 83.67 & 82.33 & 81.33 & 81.67 & 81.50 \\
\hline $100 \mathrm{ppm}$ & 80.00 & 81.00 & 80.50 & 79.67 & 79.67 & 79.67 \\
\hline $150 \mathrm{ppm}$ & 84.33 & 83.67 & 84.00 & 84.67 & 83.00 & 83.83 \\
\hline Mean & 81.67 & 82.92 & - & 81.92 & 81.75 & - \\
\hline & F test & & LSD 0.05 & F test & & LSD 0.05 \\
\hline ZnONPs & ns & & - & $*$ & & 0.99 \\
\hline Cultivars & $*$ & & 2.01 & ns & & - \\
\hline Interaction & ns & & Ns & ns & & $\mathrm{ns}$ \\
\hline
\end{tabular}

Table 4. Effect of zinc oxide nanoparticles concentrations, grain sorghum cultivars and their interaction on panicle length/ plant.

\begin{tabular}{|c|c|c|c|c|c|c|}
\hline $\begin{array}{ll}\text { Seasons } & \\
& \text { Cultivars } \\
\end{array}$ & \multicolumn{3}{|c|}{2017} & \multicolumn{3}{|c|}{2018} \\
\hline Zinc oxide Cultivars & Giza 15 & Dorado & Mean & Giza 15 & Dorado & Mean \\
\hline control & 8.63 & 7.43 & 8.03 & 8.73 & 7.50 & 8.12 \\
\hline 50 ppm & 8.80 & 7.73 & 8.27 & 9.30 & 7.93 & 8.62 \\
\hline $100 \mathrm{ppm}$ & 9.17 & 8.63 & 8.90 & 9.33 & 8.67 & 9.00 \\
\hline $150 \mathrm{ppm}$ & 8.80 & 7.93 & 8.37 & 9.03 & 7.43 & 8.23 \\
\hline \multirow[t]{2}{*}{ Mean } & 8.85 & 7.93 & - & 9.10 & 7.88 & - \\
\hline & $\mathrm{F}$ tes & & LSD 0.05 & $\mathrm{~F}$ tes & & LSD 0.05 \\
\hline ZnONPs & $*$ & & 0.26 & $* *$ & & 0.42 \\
\hline Cultivars & $* *$ & & - & $* *$ & & - \\
\hline Interaction & ns & & Ns & ns & & Ns \\
\hline
\end{tabular}

*and ** mean significant 5 and $1 \%$ at level of probability, respectively.

Table 5. Effect of zinc oxide nanoparticles concentrations, grain sorghum cultivars and their interaction on panicle width. *and

\begin{tabular}{|c|c|c|c|c|c|c|}
\hline Seasons & \multicolumn{3}{|c|}{2017} & \multicolumn{3}{|c|}{2018} \\
\hline Zinc oxide Cultivars & Giza 15 & Dorado & Mean & Giza 15 & Dorado & Mean \\
\hline control & 18.40 & 21.80 & 20.10 & 18.47 & 21.87 & 20.17 \\
\hline $50 \mathrm{ppm}$ & 19.70 & 23.10 & 21.40 & 19.20 & 23.00 & 21.10 \\
\hline $100 \mathrm{ppm}$ & 20.73 & 23.80 & 22.27 & 21.47 & 23.23 & 22.35 \\
\hline $150 \mathrm{ppm}$ & 20.77 & 22.43 & 21.60 & 20.63 & 22.57 & 21.60 \\
\hline Mean & 19.90 & 22.78 & - & 19.94 & 22.67 & - \\
\hline & F test & & LSD 0.05 & F test & & LSD 0.05 \\
\hline $\mathrm{ZnONPs}$ & $*$ & & 0.98 & $* *$ & & 1.23 \\
\hline Cultivars & $* *$ & & - & $*$ & & - \\
\hline Interaction & ns & & Ns & * & & 1.03 \\
\hline
\end{tabular}


Table 6. Effect of zinc oxide nanoparticles concentrations, grain sorghum cultivars and their interaction on grain yield / plant.

\begin{tabular}{|c|c|c|c|c|c|c|}
\hline \multirow{2}{*}{$\begin{array}{l}\text { Seasons } \\
\text { Cultivars }\end{array}$} & \multicolumn{3}{|c|}{2017} & \multicolumn{3}{|c|}{2018} \\
\hline & Giza 15 & Dorado & Mean & Giza 15 & Dorado & Mean \\
\hline control & 44.70 & 35.50 & 40.10 & 43.90 & 35.93 & 39.92 \\
\hline $50 \mathrm{ppm}$ & 44.67 & 38.23 & 41.45 & 44.33 & 39.43 & 41.88 \\
\hline $100 \mathrm{ppm}$ & 48.63 & 41.10 & 44.87 & 49.73 & 40.07 & 44.90 \\
\hline $150 \mathrm{ppm}$ & 47.43 & 38.73 & 43.08 & 46.47 & 39.30 & 42.88 \\
\hline Mean & 46.36 & 38.39 & - & 46.11 & 38.68 & - \\
\hline & F test & & LSD 0.05 & F test & & LSD 0.05 \\
\hline ZnONPs & $* *$ & & 1.15 & $* *$ & & 1.68 \\
\hline Cultivars & $* *$ & & - & $* *$ & & - \\
\hline Interaction & ns & & Ns & $*$ & & 2.26 \\
\hline
\end{tabular}

*and $* *$ mean significant 5 and $1 \%$ at level of probability, respectively.

Table 7. Effect of zinc oxide nanoparticles concentrations, grain sorghum cultivars and their interaction on 1000 kernel weight.

\begin{tabular}{|c|c|c|c|c|c|c|}
\hline Seasons & \multicolumn{3}{|c|}{2017} & \multicolumn{3}{|c|}{2018} \\
\hline Zinc oxide Cultivars & Giza 15 & Dorado & Mean & Giza 15 & Dorado & Mean \\
\hline control & 32.87 & 23.63 & 28.25 & 32.43 & 24.47 & 28.45 \\
\hline $50 \mathrm{ppm}$ & 34.47 & 24.70 & 29.58 & 34.63 & 25.67 & 30.15 \\
\hline 100 ppm & 37.63 & 26.83 & 32.23 & 38.33 & 26.77 & 32.55 \\
\hline $150 \mathrm{ppm}$ & 34.47 & 25.03 & 29.75 & 34.50 & 24.97 & 29.73 \\
\hline Mean & 34.86 & 25.05 & - & 34.97 & 25.47 & - \\
\hline & $\mathrm{F}$ tes & & LSD 0.05 & F tes & & LSD 0.05 \\
\hline $\mathrm{ZnONPs}$ & $*$ & & 0.87 & $*$ & & 0.62 \\
\hline Cultivars & $* *$ & & - & $* *$ & & - \\
\hline Interaction & ns & & Ns & * & & 1.78 \\
\hline
\end{tabular}

Lower doses of nano $\mathrm{ZnO}$ is sufficient to achieve positive response and higher doses showed growth retardation. Results depicted clearly indicate that ZnO NPs at 100 ppm significantly induced early flowering and seed yield in treated grain sorghum plants. The increase in vegetative growth in other crops (Onion) might be due to fundamental role of $\mathrm{Zn}$ in protecting and maintaining structural stability of cell membranes (Welch et al., 1982) and use in protein synthesis, membrane function, cell elongation as well as tolerance to environmental stresses (Cakmak, 2000). Also, ( Poornima and Koti, 2019) shows that application of nano $\mathrm{ZnO}$ recorded more yield and growth of sorghum as compare to bulk ZnSO4. In Egypt Mourad and El-Menshawi (2005), reported that grain weight per head , number of kernel per head and grain yield increased significantly by raising zinc level up to $0.5 \mathrm{gm} / \mathrm{L}$ whereas the same characters decreased significantly by spraying one grain zinc per liter.

\section{Conclusion}

Plant height, panicle length, panicle width, 1000 kernel weight and grain yield / plant were affected highly significant or significant by different zinc oxide nanoparticles in the two growing seasons, except $50 \%$ flowering was insignificant in both seasons. Grain sorghum plants which were sprayed by $1{ }^{\prime}$ ppm $\mathrm{ZnO}$ NPs gave the highest mean values of grain yield /plant over both cultivars. The same trend was observed for 1000-kernel weight, since the highest mean values of two cultivars obtained from plants which sprayed by $100 \mathrm{ppm} \mathrm{ZnO}$ Nps. The interaction between $\mathrm{ZnO}$ NPs concentrations and genotypes had a non significant effect on the all studied traits in the first season, while in the second season the 
interaction between $\mathrm{ZnO}$ NPs concentrations and genotypes had significant effects on plant height, panicle length, grain yield / plant and 100. kernel weight.

\section{References}

Cakmak, I. (2000) 'Role of zinc in protecting plant cells from reactive oxygen species' New Phytologist, pp. 146, 185 - 205.

Dy Kes and Lloyd, w. Rooney. (2006) 'Sorghum and millet phenols and antioxidants' Journal of cereal science, pp. 44 pages 236- 251.

El-Rawi, K. and A.M. Khalafalla, 1980. Design and analysis of agricultural experiments, El Mousel Univ., Iraq, 19.

Gomez, K.A. and Gomez, A.A. (1984) 'Statistical Procedures for Agricultural Research' 2nd Edn., John Wily and Sons, New York, pp: 68.

Mazaherinia, S., Astaraei, A.R., Fotovat, A., Monshi, A. (2010) 'Nano iron oxide particles efficiency on $\mathrm{Fe}, \mathrm{Mn}, \mathrm{Zn}$ and $\mathrm{Cu}$ concentrations in wheat plant' Word applied Science Journal, pp.7(1):36-40.

Mortvedt, J.J. (1992) 'Crop response to level of water soluble zinc in granular zinc fertilizers' Fertilizer Res, pp. 33: 249-255.

Naderi, M.R. and Abedi, A. (2012) 'Application of nanotechnology in agriculture and refinement of environmental pollutants' Journal of Nanotechnology, pp. 11(1):1826.

Mourad, A.C.A.A. and El-Menshawi, M.M. (2005) 'Effect of adding nitrogen, potassium and zinc on growth and yield on grain sorghum hybrid (Shandaweel 2) In sandy soils. Egypt' J. of App. Sci., pp. 20 (8A): 127-138.

Poornima, R. and Koti, R.V. (2019) 'Effect of nano zinc oxide on growth, yield and grain zinc content of sorghum (Sorghum bicolor)' Journal of Pharmacognosy and Phytochemistry, pp. 8(4): 727-731.

Pontieri, P., Mario, A.Di., Tamburino, R., stelano, M. De., Tilley, M., Bean, S.R., Roemer, E., Vita, P.De., Vita, Alifano, P.S., Givdice, L. Del., and Massardo, D.R. (2010) 'Chemical composition of selected food - grads sorghum varieties'

Prasad, T.N.V.K.V., Sudhakar, P., Sreenivasulu, Y., Latha, P., Munaswamy, V., Raja Reddy, K., Sreeprasad, T. S., Sajanlal,P. R. and Pradeep, T. (2012) 'Effect of nanoscale zinc oxide particles on the germination, growth and yield of peanut' Journal of Plant Nutrition, pp. (35), 905-927.

Reynolds, G.H. (2002) 'Forward to the future nanotechnology and regulatory policy' Pacific Research Institute, pp. 24,1-23.

SAS institute (2008) 'The SAS System for Windows, release 9.2 ' Cary NC: SAS institute.

Welch, R.M., Webb, M.J. and Loneragan, J.F. (1982) 'Zinc in membrane function and its role in phosphorus toxicity ' In: Proceedings of the Ninth Plant Nutrition Colloquium, ed. A. Scaife, pp710 -715. Wallingford, UK: CAB International. 